\section{Canopy Growth, Yield, and Fruit Quality of 'Royal Gala' Apple Trees Grown for Eight Years in Five Tree Training Systems}

\author{
Cheryl R. Hampson, Harvey A. Quamme, and Robert T. Brownlee \\ Agriculture and Agri-Food Canada, Pacific Agri-Food Research Centre, \\ Summerland, BC, Canada VOH $1 \mathrm{ZO}$
}

Additional index words. Malus $\times$ domestica, trunk cross-sectional area, yield efficiency, fruit size, fruit color, light interception, high density planting

\begin{abstract}
In 1993, a planting of virus-free 'Royal Gala' apple (Malus $\times$ domestica Borkh.) on 'M.9' rootstock was established at Summerland, B.C., Canada, to determine whether angled-canopy training systems could improve orchard tree performance relative to slender spindles. The trees were trained in one of five ways: slender spindle (SS), Geneva Y-trellis (GY), a modified Solen training we called 'Solen Y-trellis' (SY), or V-trellis (LDV), all at the same spacing $(1.2 \mathrm{~m} \times \mathbf{2 . 8} \mathrm{m})$, giving a planting density of 2976 trees/ha. In addition, a higher density (7143 trees/ha) version of the V-trellis (HDV) was planted to gauge the performance of this system at densities approaching those of local super spindle orchards. The plots were drip-irrigated and hand-thinned. No summer pruning was done. After 8 years, differences among training systems at the same density and spacing were small and few. The two Y-shaped training systems had $11 \%$ to $14 \%$ greater cumulative yield/ha than the SS, but did not intercept significantly more light at maturity. No consistent differences occurred in fruit size or the percentage of fruit with delayed color development among the four training systems at the same density. Relative to the LDV, the HDV yielded less per tree, but far more per hectare, particularly in the first 3 years. After 8 years, the cumulative yield/ha was still $65 \%$ greater than with LDV. Yield efficiency was unaffected by tree density. Fruit size on HDV ranked lowest among the systems nearly every year, but was still commercially acceptable. The HDV intercepted more light $(73 \%)$ than SS $(53 \%)$. The percentage of fruit with delayed color development in HDV was not significantly different from that for $\mathrm{LDV}$ in most years. The trees in HDV were difficult to contain within their allotted space without summer pruning. The substantially similar performance of all the training systems (at a given density, and with minimal pruning) suggests that cost and ease of management should be the decisive factors when choosing a tree training method.
\end{abstract}

Economic considerations in apple production have spurred the widespread adoption of high density plantings of dwarf trees during the past two decades. Such orchards offer the advantages of early production, sustained high yields of high-quality fruit, and lower labor costs, but establishment costs are high.

High density plantings make better use of the available light ["light" in this context refers to photosynthetically active radiation, $(P A R)]$ than conventional low density plantings. Two factors are involved: 1) the rate of increase in light interception with orchard age is greater in high density plantings; and 2) light distribution within the canopy is better. Dwarf trees at close spacing intercept a greater proportion of the incoming light, by virtue of high leaf area spread more uni-

Received for publication 9 Apr. 2001. Accepted for publication 10 Oct. 2001. Agriculture and AgriFood Canada contribution no. 2119. The statistical and editorial advice of John W. Hall and the technical assistance of Mark Neufield, Ron Harris, Keith Johnstone, Bob Lawrence, George Sajna, Brent Tiffin, Bill Whiting, and seasonal farm staff are gratefully acknowledged. Frank Kappel made helpful comments on the manuscript. formly over the surface area of the orchard. Yield and fruit quality depend on light distribution in the canopy as well as total interception. The adverse effects of shaded canopies on flower bud induction, spur quality, and fruit size, color and internal quality are consistent and well-documented (Barritt et al., 1997; Callesen and Wagenmakers, 1989; Palmer, 1999b; Parry, 1981; Verheij and Verwer, 1973; Warrington et al., 1996). Some sacrifice to total interception is required to achieve the good light penetration into the lower canopy that is necessary for maximum fruit quality (Verheij and Verwer, 1973).

Light interception and distribution are determined by a complex interplay of factors (Jackson, 1980). Previous work has established that $P A R$ interception, distribution, or both, are optimized with high tree density, square tree layout (low rectangularity), northsouth row orientation, and dwarf trees with canopies of low leaf area density that spread over adjacent alleys (Jackson, 1989; Palmer, 1999b; Wertheim, 1985). Optimum tree height varies with latitude and alley width (Wagenmakers and Callesen, 1989, 1995). Rootstocks impact light use by influencing scion leaf area, tree size, and vigor, and they impact yield by affecting the relative partitioning of photosynthate into fruit growth (Palmer, 1999b).

A tree training system is a method of manipulating tree planting arrangement and canopy geometry to improve the interception and distribution of $P A R$, for the purpose of optimizing fruit quality and yield. Many comparisons of training systems have been reported in the past two decades, and some researchers have purported to find more efficient systems. However, the best-performing systems have usually been the ones with the greatest tree density, or the most efficient rootstock. The contribution of the training system in the absence of these confounding factors is unclear.

Very few studies offer a direct comparison of training systems with identical tree density, spacing and rootstock. Clayton-Greene (1993) reported on the growth and yield of 'Granny Smith' and 'Starking Delicious' trees trained eight different ways. After 7 years, the training system had only minor effects on performance compared with density. At a given density, he found no evidence for differences in leaf area index or yield among systems, but systems did vary in fruit size and color, the incidence of certain fruit defects, and in yield efficiency. Fruit quality effects were associated with differences in light and wind exposure (Clayton-Greene, 1993; Ferree et al., 1993). Unfortunately no fruit thinning was done in this experiment.

Robinson (1992) found that early fruit yields were primarily a function of density, but after 6 years, the cumulative yield (CY) was higher on the Geneva Y-trellis than on central leader trees, provided the angle of the Y-trellis was between $50^{\circ}$ and $70^{\circ}$. CY after 8 years on the Y-trellis was $8 \%$ to $15 \%$ greater than with slender spindle or vertical axis training (Robinson, 1997). The Y-trellis intercepted more light and had higher partitioning efficiency. In a separate trial, trees trained as vertical axes or on a Y-trellis differed in neither interception nor yield by year six, if the vertical axis was grown to an optimal height: alley width ratio (Robinson, 1997). In a study of density and training system at constant rectangularity, trees trained as Y-trellis, slender spindle, or modified vertical axis showed no differences in interception, yield, yield efficiency, trunk girth, or canopy spread for the first 5 years (Hampson et al., 1997, 1998). Thereafter the Y-trellis intercepted more light and slightly out yielded the other two systems (unpublished data). No direct comparisons involving $\mathrm{V}$ trellises could be located in the literature. All these authors remarked on the striking similarity in performance among very different tree shapes and training strategies when other factors were held constant and pruning was minimized.

At the time this trial was initiated, slender spindle was the local training system of choice for new plantings, and very high density superspindle plantings (5000-10000 trees/ha) were increasing rapidly in popularity. Growers in the Pacific Northwestern United States 
were planting $\mathrm{V}$ trellises at high density. Given the prospects of better yield performance from the spreading canopies of angled trellises, our objectives were to: 1) determine whether Y or $\mathrm{V}$-shaped canopy architecture could improve orchard performance relative to slender spindles, if rootstock and tree spacing were held constant; and 2) determine the effect of increasing tree density to approach that of local super spindle plantings, on the performance of the $\mathrm{V}$ trellis. Initial results of this trial were outlined previously (Hampson et al., 1998).

\section{Materials and Methods}

Planting description. Trees of virus-free 'Royal Gala' on virus-free 'M.9' rootstock were grown for one year in the nursery at the research center. The feathered (i.e. branched) trees were planted in north-south rows in spring 1993, into a light sandy loam [Naramata orthic brown soil (Wittneben, 1986)] that had previously grown grape vines for 10 years. No preplanting fumigation was done. Pressure-treated posts (5-7.5 $\mathrm{cm}$ diameter, $2.4 \mathrm{~m}$ long) were installed before planting. The nursery trees were graded before planting, and the best feathered trees were chosen for the experimental trees. The rest were used as guard trees. Trunk cross-sectional area (TCA) at planting was uniform for all training systems (TCA = $\left.1.3-0.1 \mathrm{~cm}^{2}\right)$. Trees were planted with the bud union $\approx 5 \mathrm{~cm}$ above the soil line. After planting, trees were watered in by hand, and overhead-irrigated until the drip irrigation was installed (Summer 1993). Trellis installation was completed in Summer 1993.

Tree spacing was $1.2 \mathrm{~m} \times 2.8 \mathrm{~m}$ for all systems except the high-density $\mathrm{V}$, where spacing was $0.5 \mathrm{~m} \times 2.8 \mathrm{~m}$. Resultant tree densities were 2976 and 7143 trees/ha respectively. Training treatments were as follows. 1) Slender spindle (SS) - the trees were trained classically (Wertheim, 1978), with a final target height of $2.5 \mathrm{~m}$. Trees were headed at $0.9 \mathrm{~m}$ and planted $15 \mathrm{~cm}$ south of the posts with the bud union facing the post. 2) Geneva Y-trellis (GY) - the trees were trained according to Robinson et al. (1989). The trellis was $2.0 \mathrm{~m}$ high, the junction of the $\mathrm{Y}$ arms was $0.6 \mathrm{~m}$ above ground and the angle of the $\mathrm{Y}$ was $60^{\circ}$. Trellis wires were at $0.9,1.5$, and $1.8 \mathrm{~m}$ heights above the ground. The arms of the $\mathrm{Y}$ were formed of lumber $(3.8 \mathrm{~cm} \times 8.9 \mathrm{~cm})$. 3) $\mathrm{V}$ trellis (LDV) - the trees were planted to lean alternately to one side or the other of the trellis. The V trellis arms were set so that both GY and LDV trellises were $2.0 \mathrm{~m}$ wide at the top and $2.0 \mathrm{~m}$ high. The arms of the $\mathrm{V}$ were formed of lumber $(3.8 \mathrm{~cm} \times 8.9 \mathrm{~cm})$ with support wires at $0.5,0.8,1.2,1.6$, and $2.0 \mathrm{~m}$. The trees were headed at $0.9 \mathrm{~m}$ and the branches trained as a fan along the trellis. The system resembled the "mini-V trellis" described by Robinson (2000). 4) high density V (HDV) - the trees were trained as for the LDV but in-row spacing was 0.5 m. 5) Solen Y-trellis (SY) - the classical Solen training (Lespinasse and Delort, 1988) was modified. Branches were trained upward into a Y shape rather than horizontally along a wire. The $\mathrm{Y}$ junction was $0.85 \mathrm{~m}$ above the ground, and the angle of the $\mathrm{Y}$ was $60^{\circ}$. Support wires were at $0.7,0.8,1.1,1.4,1.6$, 2.0 , and $2.3 \mathrm{~m}$, and the trellis was $2.3 \mathrm{~m}$ high. Trees for the SY were pruned after planting and two branches selected as cordons during the following growing season. The two cordons were curved back on themselves and placed along the bottom wire of the trellis, with secondary branches trained upward along the wires. An important advantage of the SY was that the $\mathrm{Y}$ junction was higher than for GY, making picking and branch training easier to perform. For diagrams of these training systems, see Hampson et al. (1998). In all training systems, pruning was kept to a minimum; no summer pruning took place.

The experiment was laid out in a randomized complete-block design with four blocks, each consisting of three rows of trees. Each experimental plot contained five trees in each of the three rows. Data were collected from the three central trees in the middle row using the remaining trees as guards. For ease of trellis installation, the training systems were assigned to the plots by restricted randomization, so that the two V systems were always side by side, as were the two Y systems. Swards of 'Alke' ryegrass (Lolium perenne L.) were planted between the rows, and weed-free strips $1.5 \mathrm{~m}$ wide were maintained under the tree rows with herbicides.

Cultural practices. The field was irrigated each year from mid-April to mid-October. Irrigation design was made difficult by the different tree spacings. We chose to water on a per area basis. Drip irrigation with a $0.9-\mathrm{m}$ emitter spacing was used to supply a uniformly wet surface. In 1993, the drippers were on $3 \mathrm{~d}$ per week for $4 \mathrm{~h}$ per day. In subsequent years, the schedule was changed to accommodate the fast-draining soil; drippers were on daily for $2 \mathrm{~h}$ per day. The total water applied was 775 L per emitter in 1993, and 1300-1330 L per emitter annually during 1994-2000 (or roughly $8.5 \mathrm{~L} \cdot \mathrm{m}^{-1}$ per day along the row, but varying over the season). Overhead irrigation in July and August supplemented the planting during hot weather and kept the ryegrass alive (average 10-22 cm, depending on the year).

All trees were fertigated with $19 \mathrm{~g}$ of 20 20-20 per tree per year from irrigation startup, followed by $15.5-0-0$ at $75 \mathrm{~g} \cdot \mathrm{m}^{-1}$ of row . All fertigation was completed by 15 Aug. each year. In Mar. 1998, a ground application of $14-16-0$ at $18 \mathrm{~kg} \cdot \mathrm{ha}^{-1}$ was made. Foliar micronutrients and pesticides were applied as necessary according to provincial recommendations for commercial growers in the B.C. interior. Fruit were hand-thinned to be $15 \mathrm{~cm}$ apart.

Measurements and statistical analysis. Trunk diameter was measured $15 \mathrm{~cm}$ above the bud union with digital calipers at planting and every year after harvest. The average of two readings (taken across and along the row) was converted to trunk cross-sectional area (TCA) for analysis. Tree height and maximum canopy spread (average of across-row and along-row measures) were also recorded yearly. The trees were first cropped in 1994.
Yield ( $\mathrm{kg} /$ tree), fruit number, and the number and weight of drops + culls were recorded annually for each tree. 'Gala' is a multiple, selective-pick cultivar. Separate records were kept for each pick date and the accumulated totals used for analysis. The proportion by weight on the last pick was also calculated. The weight of dormant-season prunings (sum of the three trees per system per block) was recorded in 1994, 1995, and 1998.

PAR interception at the base of the canopy was measured in Aug. 1998-2000 inclusive, using a 1-m line quantum sensor (LI-1915; LI-COR, Lincoln, Nebr.). Measurements were done before harvest; it has previously been shown that the contribution of fruit to total interception is very small (Verheij and Verwer, 1973; Wagenmakers, 1991). Measurements were taken on cloudless days within $2 \mathrm{~h}$ either side of solar noon. PAR readings were taken along two mid-alley to mid-alley transects: next to the trunk of the central experimental tree on the south side, and midway between this trunk and the trunk of the neighboring tree to the south. Full-sun $P A R$ was measured before and after each transect. $P A R$ interception was expressed as a percentage of full sun readings.

All variables except average fruit weight were analyzed by analysis of variance, with training systems, blocks, training systems $\times$ blocks and residual error (among trees within plots) as the sources of variation. The training system $\times$ block interaction was used as the experimental error except when it was not significantly greater than the variation among trees within plots. In the latter case, the variation among trees within plots was used in the statistical tests because it provides a better estimate (more degrees of freedom) under these circumstances (John W. Hall, personal communication). Mean separation was carried out using the Waller-Duncan K-ratio test $($ K-ratio $=100)$

Average fruit weight (AFW) is affected by crop load and, despite efforts to thin all treatments equally, crop load varied among training systems in most years. To adjust for the effect of crop load (expressed as fruit number/ $\mathrm{cm}^{2}$ TCA; Robinson et al., 1991), it was included as a quantitative source of variation in the analysis of variance. The AFW adjusted for differences in crop load is reported. Mean separation was carried out using the least significant difference test because the WallerDuncan K-ratio test was not available for adjusted values. All analyses were conducted using the SAS statistical package (SAS Institute, Cary N.C.).

\section{Results and Discussion}

Vegetative growth and light interception. The trees reached their final height and spread by about year four. Subsequently height and spread fluctuated slightly each year due to pruning, while TCA continued to increase (Table 1). Among the four systems with the same tree density, SY had smaller TCA than SS or LDV. The severe pruning necessary to establish the two major cordons on the SY may 
explain its smaller trunk size. Final height and spread were about the same for all systems, except that branches were able to spread out farther along the row for LDV, with its alternating tree arrangement.

Compared to the LDV, the HDV trees had smaller TCA and spread, but similar height (Table 1). However the HDV was too vigorous for its spacing and became self-shading and difficult to contain. Winter removal of vigorous branches perpetuated the excess vigor. Summer pruning has often been recommended in high density plantings to restrict tree size, but whether it does so better than dormant pruning is subject to debate (Mika, 1986; Saure, 1987). Close in-row spacing has previously been found to reduce TCA and encourage undesirable "top heavy" growth (Cripps et al., 1975; Palmer et al., 1992; Parry, 1981).

Among the four systems with equal tree spacing, the amount of pruning was least for SY initially, but after the trees reached full canopy (year 6), the systems did not differ significantly (Table 2). In accordance with our impression that the HDV trees were difficult to keep within their allotted space, significantly more wood was removed from HDV than from LDV at full canopy (Table 2). Time spent with summer training was not recorded, but the Y systems were the most time-consuming because of branch tying in the first few years. The time required for tree training is an acknowledged drawback with angled trellises, although it can be done with relatively unskilled labor (Robinson, 2000).

$P A R$ interception was measured for 3 years after the trees had filled their space. At this time all training systems intercepted about the same amount of light, with the exception of SS, which intercepted significantly less than HDV (Table 3). Total interception at maturity was close to the $60 \%$ to $70 \%$ considered optimal by Robinson (1997) and Verheij and Verwer (1973). A number of previous studies have reported greater light interception with angled canopies, but few of them held rootstock and tree spacing constant. GY intercepted more light than central leader trees compared on an equal basis, but did not intercept more than tall vertical axis trees (Robinson, 1997). In the present study, angled canopies intercepted slightly more PAR than SS, most likely due to the greater interception over the alleys, but the difference was not statistically significant. Wertheim et al. (1986) obtained $65 \%$ to $69 \%$ interception with SS in Holland, slightly higher than that found here. The lower interception of SS here suggests that the trees may not have been tall enough for the alley width used. Robinson (1997) emphasizes the importance of optimizing the tree height : alley width ratio to achieve adequate interception with pyramidal trees.

In this study, a $140 \%$ increase in tree density produced no statistically significant gain in light interception at orchard maturity (Table $3)$. Light interception was not measured prior to year 6 , but it is well-established that the chief advantage of high density occurs within the first 3 to 4 years, and afterward diminishes as lower density plantings fill their allotted
Table 1. Trunk cross-sectional area (TCA), tree height, and maximum canopy spread of dwarf 'Royal Gala' apple trees grown under five different training systems.

\begin{tabular}{|c|c|c|c|c|c|c|}
\hline \multirow[b]{2}{*}{ System } & \multicolumn{3}{|c|}{ Fourth leaf } & \multicolumn{3}{|c|}{ Eighth leaf } \\
\hline & $\mathrm{TCA}\left(\mathrm{cm}^{2}\right)$ & Height (m) & Spread $(\mathrm{m})$ & $\mathrm{TCA}\left(\mathrm{cm}^{2}\right)$ & Height (m) & Spread $(\mathrm{m})$ \\
\hline Slender spindle & 12.36 & 2.46 & 1.73 & 25.36 & 2.73 & 1.82 \\
\hline Low density V & 11.73 & 2.50 & 2.02 & 23.03 & 2.90 & 2.87 \\
\hline Geneva Y & 10.48 & 2.02 & 1.47 & 21.68 & 2.66 & 1.81 \\
\hline Solen $\mathrm{Y}^{\mathrm{z}}$ & 8.93 & 2.20 & 1.64 & 17.83 & 2.73 & 1.67 \\
\hline High density V & 8.55 & 2.76 & 1.52 & 16.08 & 2.96 & 1.76 \\
\hline $\mathrm{MSD}^{\mathrm{y}}$ & 2.62 & 0.34 & 0.18 & 5.90 & 0.43 & 0.22 \\
\hline Error term & $\mathrm{T} \times \mathrm{B}^{\mathrm{x}}$ & $\mathrm{T} \times \mathrm{B}$ & Residual & $\mathrm{T} \times \mathrm{B}$ & $\mathrm{T} \times \mathrm{B}$ & Residual \\
\hline $\operatorname{SE}(n=12)$ & 0.80 & 0.11 & 0.07 & 1.79 & 0.11 & 0.09 \\
\hline
\end{tabular}

${ }^{\mathrm{z}}$ One tree died in 2000, making $\mathrm{n}=11$ for the eighth leaf figures in this treatment.

${ }^{\mathrm{y}}$ Minimum significant difference for the Waller-Duncan K-ratio $t$ test $(\mathrm{K}$ ratio $=100)$.

${ }^{\mathrm{x}} \mathrm{T} \times \mathrm{B}=$ mean square for training system $\times$ block interaction.
Table 2. Weight of wood removed $\left(\mathrm{kg} \cdot \mathrm{m}^{-1}\right.$ of row $)$ during dormant pruning of 'Royal Gala' trees grown under different training systems.

\begin{tabular}{llcl}
\hline System & Year 2 & Year 3 & Year 6 \\
\hline Slender spindle & 0.260 & 0.803 & 0.741 \\
Low density V & 0.203 & 0.586 & 0.799 \\
Geneva Y & 0.153 & 0.441 & 0.766 \\
High density V & 0.338 & 0.946 & 1.798 \\
Solen Y & 0.001 & 0.185 & 0.509 \\
MSD $^{z}$ & 0.112 & 0.516 & 0.820 \\
SE $(\mathrm{n}=4)$ & 0.04 & 0.15 & 0.25
\end{tabular}

${ }^{\mathrm{z}}$ Minimum significant difference for the WallerDuncan K-ratio $t$ test $(\mathrm{K}$ ratio $=100)$.

space, increasing in leaf area, interception and yield (Hampson et al., 1998; Palmer, 1999a; Palmer et al., 1989; Sansavini and CorelliGrappadelli, 1997). In this case, the LDV was intercepting a similar proportion of $P A R$ no later than year 5 .

Yield and fruit quality. Among the four systems at constant planting density, CY over the first three crops (fourth leaf, 1996) was higher for SS than SY or LDV (Table 4). GY was second most productive. The low early $\mathrm{CY}$ for $\mathrm{SY}$ is attributable to lower yields in the first two cropping years (data not shown), likely a result of the severe early pruning mentioned earlier. Heavy pruning is known to delay bearing and encourage vegetative growth (Campbell et al., 1996; Miller, 1984). Despite a "slow start", the SY was an efficient training After seven crops, it had surpassed all but GY in CY per tree, and it surpassed LDV in CY/ha (Table 4). The CY/ha in the eighth leaf was $11 \%$ to $14 \%$ higher for Y-shaped trellises than system and required little pruning (Table 2).
Table 3. Interception of photosynthetically active radiation as a percentage of full sun values at the base of the canopy of 'Royal Gala' trees grown under different training systems.

\begin{tabular}{lccc}
\hline System & Year 6 & Year 7 & Year 8 \\
\hline High density V & 72.9 & 70.0 & 76.2 \\
Solen Y & 61.6 & 69.6 & 71.9 \\
Geneva Y & 59.5 & 76.8 & 68.8 \\
Low density V & 58.4 & 65.0 & 60.6 \\
Slender spindle & 47.8 & 53.8 & 56.2 \\
MSD $^{z}$ & 15.3 & 13.6 & 16.9 \\
SE $(n=4)$ & 4.6 & 4.1 & 4.8
\end{tabular}

${ }^{\mathrm{z}}$ Minimum significant difference for the WallerDuncan K-ratio $t$ test $(\mathrm{K}$ ratio $=100)$.

SS. Robinson (1997) reported a yield advantage of $8 \%$ to $15 \%$ for GY compared with SS or vertical axis trees by year eight. A combination of small trunks and good yields produced a high CYE for SY, whereas the other three systems did not differ.

The yield advantage of high density planting was clearly evident by the third cropping year. Although HDV yielded less per tree, it produced $86 \%$ more fruit per hectare than LDV (Table 4). This advantage declined over time, but the $\mathrm{CY} /$ ha remained $65 \%$ higher by year eight. Density had no effect on CYE within the range of tree density and the duration of this study (Table 4).

Training system had no consistent effect on average fruit weight (AFW). SS had larger fruit than GY, SY and LDV in 2 years, and similar AFW in 5 years (Table 5). HDV ranked last among the systems nearly every year, and AFW was significantly smaller $(P \leq 0.05)$ than that of LDV in 3 years out of seven. AFW was nevertheless commercially acceptable regard-
Table 4. Cumulative yield (CY) per tree, cumulative yield per unit land area, and cumulative yield efficiency $\left(\mathrm{CYE}, \mathrm{kg} \cdot \mathrm{cm}^{-2}\right.$ of trunk cross-sectional area) for 'Royal Gala' apple trees in their fourth and eighth leaf (third and seventh cropping year, respectively) grown under different training systems.

\begin{tabular}{|c|c|c|c|c|c|c|}
\hline \multirow[b]{2}{*}{ System } & \multicolumn{3}{|c|}{ Fourth leaf } & \multicolumn{3}{|c|}{ Eighth leaf } \\
\hline & CY (kg) & CY (t/ha) & CYE $\left(\mathrm{kg} \cdot \mathrm{cm}^{-2}\right)$ & CY (kg) & CY (t/ha) & CYE $\left(\mathrm{kg} \cdot \mathrm{cm}^{-2}\right)$ \\
\hline Slender spindle & 22.8 & 67.8 & 1.91 & 89.5 & 266.3 & 3.61 \\
\hline Geneva Y & 21.6 & 64.3 & 2.08 & 99.3 & 295.5 & 4.70 \\
\hline Solen $\mathrm{Y}^{\mathrm{z}}$ & 19.6 & 58.2 & 2.28 & 101.7 & 302.7 & 6.00 \\
\hline Low density V & 18.6 & 55.3 & 1.77 & 86.0 & 255.7 & 3.98 \\
\hline High density V & 14.4 & 102.7 & 1.65 & 59.2 & 422.6 & 3.95 \\
\hline $\mathrm{MSD}^{\mathrm{y}}$ & 2.7 & 10.7 & 0.50 & 10.5 & 36.7 & 1.32 \\
\hline Denominator & Residual & Residual & $\mathrm{T} \times \mathrm{B}^{\mathrm{x}}$ & Residual & Residual & $\mathrm{T} \times \mathrm{B}$ \\
\hline $\operatorname{SE}(n=12)$ & 1.0 & 4.2 & 0.14 & 4.0 & 14.1 & 0.41 \\
\hline
\end{tabular}

${ }^{\mathrm{z}}$ One tree died in 2000, making $\mathrm{n}=11$ for the eighth leaf figures in this treatment.

${ }^{\mathrm{y}}$ Minimum significant difference for the Waller-Duncan K-ratio $t$ test $(\mathrm{K}$ ratio $=100)$.

${ }^{\mathrm{x}} \mathrm{T} \times \mathrm{B}=$ mean square for training system $\times$ block interaction. 
Table 5. Least-squares means for average fruit weight (adjusted for crop load) for 'Royal Gala' apple trees grown under different training systems.

\begin{tabular}{lllllllr}
\hline \hline System & Year 2 & Year 3 & Year 4 & Year 5 & Year 6 & Year 7 & Year 8 \\
\hline Slender spindle & 239 & $200 \mathrm{a}^{\mathrm{z}}$ & $212 \mathrm{a}$ & $195 \mathrm{a}$ & 215 & 185 & $177 \mathrm{a}$ \\
Low density V & 238 & $184 \mathrm{~b}$ & $181 \mathrm{bc}$ & $199 \mathrm{a}$ & 208 & 182 & $179 \mathrm{a}$ \\
Geneva Y & 233 & $184 \mathrm{~b}$ & $185 \mathrm{~b}$ & $190 \mathrm{a}$ & 214 & 181 & $174 \mathrm{a}$ \\
Solen Y & 224 & $178 \mathrm{bc}$ & $177 \mathrm{~b}-\mathrm{d}$ & $177 \mathrm{ab}$ & 210 & 176 & $180 \mathrm{a}^{\mathrm{y}}$ \\
High density V & 232 & $168 \mathrm{c}$ & $168 \mathrm{~cd}$ & $172 \mathrm{~b}$ & 206 & 178 & $163 \mathrm{~b}$ \\
SE (n = 12) & 8.4 & 4.1 & 5.3 & 6.9 & 3.0 & 4.6 & 2.7 \\
\hline
\end{tabular}

${ }^{\mathrm{z}}$ Means within a column followed by the same letter are not significantly different using the least significant difference test $(P=0.05)$.

${ }^{\mathrm{y}}$ One tree died in 2000 , making $\mathrm{n}=11$.

less of year, density or training system. The tendency for smaller AFW in HDV may be related to the close in-row spacing or high tree density. AFW has declined with increasing tree density in some previous studies (Corelli and Sansavini, 1989; Tustin et al., 1993) but not others (Mika et al., 1981; Palmer et al., 1989; Wagenmakers and Callesen, 1995). Water stress cannot be ruled out completely. Although the trees showed no overt signs of water stress, they were receiving the same irrigation per linear meter, and so less water per tree. Robinson (2000) noted that water demand may rise if greater light interception increases the heat load, but the HDV did not intercept significantly more light than the LDV at full canopy (Table 3).

'Gala' is a multi-pick apple, and the fruit are harvested according to ground and blush color development. The proportion of fruit left for the last pick can be used as an estimate of delayed and/or poor color development. Differences among systems in the proportion (by weight) of fruit on the last pick were not consistent from year to year, but SS and LDV had better color than SY in 3 out of 5 years, beginning with the third crop (Table 6). Possibly these systems have better light distribution, or earlier (or more concentrated) maturity. Many fruit on the two Y systems hung below the canopy and were shaded by leaves (the local environment has a high proportion of direct light). In our study, there was only $\approx 1.3 \mathrm{~m}$ between adjacent rows of the $\mathrm{GY}$ at the top of the trellis, rather than the $1.5 \mathrm{~m}$ recommended by its originators as essential to good color development (Robinson et al., 1989). Fruit color could probably have been improved in all systems by summer pruning. Summer pruning decreased light interception by $6 \%$ to $14 \%$ in one study (Palmer et al., 1992), and was recommended for optimum fruit color in both the GY (Robinson et al., 1989) and the Tatura trellis (van den Ende, 1994), another angled canopy design. Wertheim et al. (1986) found better fruit color but lower yield when SS were summer pruned annually. Summer pruning probably would interact with training system effects on quality and productivity.

The difference in color between HDV and LDV was small and only statistically different in year 6 (Table 6), when September was unusually hot. Fruit color is believed to be much more sensitive to shading than is fruit size. Mika and Piskor (1997) noted poorer fruit color as tree density rose. Wertheim (1985) did not find consistent color differences, but higher rectangularity seemed to reduce fruit color.

It is difficult to ascertain whether a Yshaped canopy is more productive than the $\mathrm{V}$ or pyramid forms from our data. Despite a deliberate attempt to thin all systems equally, the crop load was a little higher on the two Y systems nearly every year. In part, this was because of the difficulty of seeing the fruitlets and getting at them on the inside part of the $\mathrm{Y}$ after the trees had leafed out. The LDV had lower early CYE and ranked last in CY/hectare after 8 years (Table 4 ). The LDV also had greater canopy spread than the other systems, with similar TCA and height (Table 1), suggesting that its yield efficiency on a canopy volume basis might be lower. But visual examination of the trees contradicted this suggestion. Although they filled their space at the bottom of the trellis, the growth of upper branches on the LDV did not suffice to fill the space allotted. This situation is reflected in the slightly lower $P A R$ interception readings compared to the two Y systems (Table 3). The LDV could probably have benefitted from a slightly closer in-row spacing, but not as close as the $0.5 \mathrm{~m}$ in the HDV. An alternating layout is believed to reduce competition relative to a linear tree arrangement, so that rectangularity can be higher without deleterious effects (Robinson, 2000).

Table 6. Percentage (by weight) of fruit left for the last pick on 'Royal Gala' apple trees grown under different training systems.

\begin{tabular}{lccccc}
\hline \hline System & Year 4 & Year 5 & Year 6 & Year 7 & Year 8 \\
\hline Solen Yz & 60.5 & 23.1 & 30.7 & 3.6 & 35.0 \\
High density V & 36.7 & 31.2 & 27.1 & 6.2 & 18.5 \\
Geneva Y & 35.7 & 11.4 & 27.4 & 3.6 & 26.9 \\
Slender spindle & 24.9 & 26.3 & 14.8 & 4.1 & 10.5 \\
Low density V & 22.8 & 24.8 & 14.0 & 5.1 & 9.1 \\
MSD $^{y}$ & 15.6 & 31.0 & 11.1 & 5.7 & 9.4 \\
SE (n = 12) & 5.7 & 4.5 & 3.8 & 1.4 & 3.5
\end{tabular}

${ }^{2}$ One tree died in 2000, making $\mathrm{n}=11$.

${ }^{y}$ Minimum significant difference for the Waller-Duncan K-ratio $t$ test $(\mathrm{K}$ ratio $=100)$.
Balanced against gains of $10 \%$ to $15 \%$ in $\mathrm{CY}$ are the disadvantages of Y shaped canopies relative to SS. These include higher trellis costs, periodic tightening of wires, tree training time in years 2 to 4 , difficulty of handthinning the inside of the $\mathrm{Y}$, and possibly poorer color in some years. Color problems might be eliminated by summer pruning and increasing the distance between the rows. Summer pruning would add to labor costs. Theoretically, by increasing the distance between the rows to leave $1.5 \mathrm{~m}$ at the top of the GY for color improvement, the $\mathrm{CY} /$ hectare would fall to $\approx 276$ to $283 \mathrm{t} / \mathrm{ha}$ (i.e., not significantly different from SS or VT), unless yield per tree increased commensurately. The Solen Y was easier to hand thin and pick than the GY (no squatting was necessary to reach fruit hanging below the trellis wires), but its low yield in the first two cropping years could make it economically unattractive.

The SS and LDV were similar in many aspects of performance and the $\mathrm{V}$ trellis trees were faster to train and easier to pick than Yshaped canopies. Neither spacing in this experiment appeared ideal for the V. At the lower density, the top of the trellis was not filled. This likely contributed to better fruit color development in the LDV, but greater branch development in this zone might have improved yield slightly. In the HDV, the trees became top-dominant and difficult to contain. While summer pruning may have helped devigorate the HDV and improved color development, it represents an additional cost. Furthermore, some reports indicate that summer pruning is no more devigorating than winter pruning (Barden et al., 1989). Alternate tree removal part way through the orchard lifetime is more problematic with an alternating tree arrangement than a linear one.

In conclusion, differences among these training systems were small, with Y-shaped canopies showing $11 \%$ to $14 \%$ greater CY than SS or LDV by the eighth year. Relative to the effect of tree density, the influence of training system was minor, provided that it fulfilled the needs for light relations in canopies. No major differences in fruit quality, growth or light interception were seen among training systems at the same spacing, underlining the plastic response of the tree to canopy manipulation. In contrast, density was of key importance. High tree density drives productivity by increasing light interception of the orchard system when young, so that early yields per unit land area are much higher than with low tree density. At full canopy, even density effects decline. The substantial equivalence in performance of diverse canopy shapes suggests that factors such as trellis costs, ease of pruning and management, and the grower's personal preference may be decisive in choosing a training system.

\section{Literature Cited}

Barden, J.A., T.B.G. Del Valle, and S.C. Myers. 1989. Growth and fruiting of 'Delicious' apple trees as affected by severity and season of pruning. J. Amer. Soc. Hort. Sci. 114:184-186.

Barritt, B.H., S.R. Drake, B.S. Konishi, and C.R. 
Rom. 1997. Influence of sunlight level and rootstock on apple fruit quality. Acta Hort. 451:569 577.

Callesen, O. and P.S. Wagenmakers. 1989. Effect of tree density, tree height and rectangularity on growth, flowering, and fruit production. Acta Hort. 243:141-148.

Campbell, J.E., H.I. Nicol, and B.R. Cullis. 1996. Effect of four different canopy shapes on apple yields. Austr. J. Expt. Agr. 36:489-499.

Clayton-Greene, K.A. 1993. Influence of orchard management system on yield, quality and vegetative characteristics of apple trees. J. Hort. Sci. 68:365-376.

Corelli, L. and S. Sansavini. 1989. Light interception and photosynthesis related to planting density and canopy management in apple. Acta Hort. 243:159-174.

Cripps, J.E.L., F. Melville, and H.I. Nicol. 1975. The relationship of Granny Smith apple tree growth and early cropping to planting density and rectangularity. J. Hort. Sci. 50:291-299.

Ferree, D.C., K.A. Clayton-Greene, and B. Bishop. 1993. Influence of orchard management system on canopy composition, light distribution, net photosynthesis and transpiration of apple trees. J. Hort. Sci. 68:377-392.

Hampson, C.R., F. Kappel, H.A. Quamme, and R.T. Brownlee. 1997. Varying density with constant rectangularity: Effects on apple tree performance and yield in three training systems. Acta Hort. 451:437-442.

Hampson, C.R., H.A. Quamme, F. Kappel, and R.T. Brownlee. 1998. Effects of apple tree density and training system on productivity. Compact Fruit Tree 31:72-76.

Jackson, J.E. 1980. Light interception and utilization by orchard systems. Hort. Rev. 2:208-267.

Jackson, J.E. 1989. World-wide development of high density planting in research and practice. Acta Hort. 243:17-27.

Lespinasse, J.-M. and F. Delort. 1988. Verger pieton. Fruits et legumes 50:16-21.

Mika, A. 1986. Physiological responses of fruit trees to pruning. Hort. Rev. 8:337-378.

Mika, A., D. Chlebowska, and J. Kosmala. 1981.
Effects of long term spacing trials with apple trees. Fruit Sci. Rpt. 8:101-113.

Mika, A. and E. Piskor. 1997. Growth and cropping of dwarf 'Jonagold' ('Jonica') apple trees planted at the density ranged from 2000 to 10,000 per ha and trained as slender spindle, super spindle and V system. Acta Hort. 451:473-477.

Miller, S.S. 1984. Effect of various training systems on canopy development in four apple cultivars. Acta Hort. 146:293-303.

Palmer, J.W. 1999a. High density orchards: An option for New Zealand? Compact Fruit Tree 32:115-118.

Palmer, J.W. 1999b. Light, canopies, fruit and dollars. Compact Fruit Tree 32:119-122.

Palmer, J.W., D.J. Avery, and S.J. Wertheim. 1992. Effect of apple tree spacing and summer pruning on leaf area distribution and light interception. Scientia Hort. 52:303-312.

Palmer, J.W., G. Bünemann, S. Sansavini, P.S Wagenmakers, and F. Winter. 1989. The international planting systems trial. Acta Hort. 243:231-241.

Parry, M.S. 1981. A comparison of hedgerow and bush tree orchard systems at different withinrow spacings with four apple cultivars. J. Hort. Sci. 56:219-235.

Robinson, T.L. 1992. Performance of Y-shaped canopies at various angles in comparison with central leader trained trees. Acta Hort. 322:79-86.

Robinson, T.L. 1997. Interaction of tree form and rootstock on light interception, yield and efficiency of 'Empire', 'Delicious' and 'Jonagold' apple trees trained to different systems. Acta Hort. 451:427-436.

Robinson, T.L. 2000. V-shaped apple planting systems. Acta Hort. 513:337-347.

Robinson, T.L., A.N. Lakso, and S.G. Carpenter. 1991. Canopy development, yield, and fruit quality of 'Empire' and 'Delicious' apple trees grown in four orchard production systems for ten years. J. Amer. Soc. Hort. Sci. 116:179-187.

Robinson, T.L., A.N. Lakso, and S. Hoying. 1989. Managing the Y-trellis system. Amer. Fruit Grower 109:14-16, 22-23.

Sansavini, S. and L. Corelli-Grappadelli. 1997. Yield and light efficiency for high quality fruit in apple and peach high density planting. Acta Hort. 451:559-568.

Saure, M.C. 1987. Summer pruning effects in appleA review. Scientia Hort. 30:253-282.

Tustin, D.S., P.M. Hirst, W.M. Cashmore, I.J. Warrington, and C.J. Stanley. 1993. Spacing and rootstock studies with central leader apple canopies in a high vigour environment. Acta Hort. 349:169-177.

van den Ende, B. 1994. The Tatura trellis. Compact Fruit Tree 27:97.

Verheij, E.W.M. and F.L.F.A.W. Verwer. 1973. Light studies in a spacing trial with apple on a dwarfing and semi-dwarfing rootstock. Scientia Hort. 1:25-42.

Wagenmakers, P.S. 1991. Simulation of light distribution in dense orchard systems. Agr. and Forest Meteorol. 57:13-25.

Wagenmakers, P.S. and O. Callesen. 1989. Influence of light interception on apple yield and fruit quality relative to arrangement and tree height. Acta Hort. 243:149-159.

Wagenmakers, P.S. and O. Callesen. 1995. Light distribution in apple orchard systems in relation to production and fruit quality. J. Hort. Sci. 70:935-948.

Warrington, I.J., C.J. Stanley, D.S. Tustin, P.M. Hirst, and W.M. Cashmore. 1996. Light transmission, yield, distribution and fruit quality in six tree canopy forms of 'Granny Smith' apple. J. Tree Fruit Prod. 1:27-54.

Wertheim, S.J. 1978. Pruning of slender spindle type trees. Acta Hort. 65:173-180.

Wertheim, S.J. 1985. Productivity and fruit quality of apple in single-row and full-field planting systems. Scientia Hort. 26:191-208.

Wertheim, S.J., A. de Jager, and M.J.J.P. Duyzens. 1986. Comparison of single-row and multi-row planting systems with apple, with regard to productivity, fruit size and color, and light conditions. Acta Hort. 160:243-258.

Wittneben, U. 1986. Soils of the Okanagan and Similkameen valleys. MOE Technical Report 18. British Columbia Ministry of Environ., Victoria, B.C., Canada. 